\title{
All headaches are not equal: A review of migraine as a state of brain dysfunction
}

\author{
De Wet Wolmarans, ${ }^{* 1}$ Sarel J Brand, ${ }^{2}$ Linda Brand ${ }^{1}$ \\ ${ }^{1}$ Centre of Excellence for Pharmaceutical Sciences, Division of Pharmacology, Faculty of Health Sciences, North West-University, \\ Potchefstroom, South Africa \\ 2 Unit for Environmental Sciences and Management, North-West University, Potchefstroom, South Africa \\ *Corresponding author, email: dewet.wolmarans@nwu.ac.za
}

\section{Introduction and background}

Individuals suffering from migraine headache, or migraineurs as they are often referred to, and the clinicians treating them are well-informed of the excruciating and debilitating nature of such episodes. However, the theoretical definition of migraine, i.e. $a$ primary, recurrent and mostly unilateral headache characterised by throbbing pain, ${ }^{1}$ also seems to describe the presentation of often non-migraine headaches, thus somewhat failing to encompass the actual incapacitating nature of the condition. Importantly, migraine is diagnosed according to criteria stipulated by the International Headache Society (IHS) ${ }^{1} 1$ ) if patients experience 5 or more attacks of unilateral, pulsating, moderate to severe pain that last 4-72 hours, 2) if such attacks are associated with nausea and/or photo- and phonophobia, and 3 ) if they are aggravated by, or prevent patients from engaging in normal routine physical activity. ${ }^{1}$ Interestingly, migraine is regarded as episodic or acute if it occurs less than 15 times per month, while chronic migraine is defined as more than 15 episodes per month continuing for more than 3 consecutive months. ${ }^{2}$ Considering that a single attack can last up to 72 hours, ${ }^{1}$ and that clinicians often design therapeutic intervention based on accurate diagnoses, this classification seems somewhat counterintuitive. Indeed, patients will often regard a single migraine attack as one too many, with 15 migraine episodes per month essentially equating to permanent incapacity. ${ }^{3,4}$

Migraine is one of the leading causes of disability worldwidethe first neurological disorder and the only headache disorder included in this list, ${ }^{5}$ and occurs in up to $18 \%$ of the general population. ${ }^{6}$ The condition also demonstrates a male to female ratio of $1: 3$, while up to $37 \%$ of women between the ages of 25 and 55 will suffer from migraine at least once during this time. ${ }^{7}$ The fact that migraine pain originates as a neurological dysfunction and demonstrates some pathophysiological overlap with epilepsy, ${ }^{8}$ necessitates a unique approach to its management, which should be done in a manner appropriate for its phenomenology. This is an argument that we will constantly put forward and highlight throughout this review.

\section{Migraine as a state of brain dysfunction and neuronal hypersensitivity}

Briefly, migraine results from aberrant activity in the trigeminovascular system in the meninges and can be divided into four phases that often, but not always, transpire in sequence. ${ }^{9}$

The premonitory phase - starting as early as 3 days before the actual pain ${ }^{10}$ - involves the sensitization of meningeal nociceptors and results from a complex interplay between homeostatic changes and hypothalamic hyperresponsiveness. ${ }^{9}$ During this phase, patients can already present with fatigue, food cravings, mood swings, yawning, myalgia, photophobia, nausea and rhinorrhoea. ${ }^{11}$ These symptoms tend to point to altered autonomic nervous system functioning and it is believed that changes in sympathetic and parasympathetic outflow during states of increased physiological or psychological stress may contribute to triggering peripheral pro-nociceptive signalling in the trigeminovascular neurons. ${ }^{12}$ That said, the subsequent cortical interpretation of such nociceptive signals originating from sensitised trigeminal neurons is modulated by the hypothalamic release of inhibitory or excitatory neurotransmitters. ${ }^{9}$ If this balance shifts towards being more excitatory, it will induce tonic firing of the trigeminovascular neurons resulting in pain transmission, with the opposite being true if the transmitters released are predominantly inhibitory. ${ }^{13}$ As the balance between excitatory and inhibitory neurotransmitter release is dependent on the brain state at the time of trigeminal sensitization, this phenomenon may explain why identical migraine triggers will not always result in headache. In summary, nociceptive trigeminovascular pathways are already sensitised during the premonitory phase following changes in the homeostatic balance, which paves the way for the propagation of nociceptive signalling. ${ }^{9}$

Second, nearly one third of migraineurs will experience sensory and neurological symptoms collectively referred to as migraine aura. ${ }^{14}$ While most patients who experience aura symptoms only report visual disturbances, transient motor and speech impairment as well as cognitive disability can also be present. ${ }^{15}$ Importantly, migraine aura is associated with a phenomenon 
broadly referred to as cortical spreading depression (CSD) that describes a slowly propagating wave of depolarization in neuronal cells that originates in the visual cortex and results in cortical inhibition for up to 30 minutes. Moreover, as the depolarizing wave proceeds, it is associated by sudden and massive changes in glutamate release as well as $\mathrm{Na}^{+}$and $\mathrm{Ca}^{2+}$ flux across neuronal membranes that is accompanied first by hyperemia-or excessive blood supply_followed by a prolonged phase of oligemia. ${ }^{16}$ This is clinically important as central perfusion rates of $<20 \mathrm{ml} / 100 \mathrm{~g} / \mathrm{min}$ is associated with ischemic neuronal cell death, which may pose a significant risk in patients already predisposed to ischemic stroke. ${ }^{17}$ In the case of stroke however, the onset of negative symptoms, e.g. numbness, often transpires suddenly as opposed to the slow progression of positive, e.g. visual disturbances, and then negative symptoms observed in migraine. ${ }^{18}$ Recently, it has been proposed that migraine with aura is founded in a distinct pathophysiological construct based on the differences in response of migraine with and without aura to oral sumatriptan intervention. ${ }^{19}$ Further, female patients presenting with aura migraine present with a twofold increased risk for ischemic stroke compared to non-aura migraineurs, pointing to a unique association between migraine with aura and aberrant vascular responses. ${ }^{7}$ Nevertheless, as migraine episodes will also occur in the majority of patients in the absence of an aura, the presence of an aura is neither necessary nor sufficient to trigger headache. While the pathophysiological role of aura in migraine episodes is still being investigated, clinicians must be attentive of the associated risks that this phenotype of migraine might possibly predict. ${ }^{16,17}$

The third phase of a migraine episode involves a severe and throbbing headache that results from activation of prior sensitised trigeminovascular neurons. Briefly, the trigeminovascular pathway relays painful stimuli from the meninges to the cortex. Nociceptive neurons from the peripheral trigeminal ganglion converge with sensory neurons from surrounding skin and pericranial muscle, which then relays pain impulses via an already sensitised trigeminovascular system to the periorbital, occipital and cervical neck regions, accounting for descriptions of pain around the eyes and the back of the head and neck, respectively. ${ }^{20}$ Activation of the prior sensitised trigeminovascular pathway begins when peripheral nociceptors that innervate the dura mater are stimulated by-at the specific time-contextually relevant triggers, e.g. bright light, dietary constituents, water deprivation, and loud noise, among others. ${ }^{21}$ Such stimulation of peripheral nociceptors elicits the release of vasoactive peptides, e.g. calcitonin gene-related peptide (CGRP) and pituitary adenylate cyclase-activating polypeptide (PACAP) and other signalling molecules, e.g. nitric oxide (NO) and glutamate, which in turn sets in motion excessive pain signalling via the trigeminovascular neuronal pathway. ${ }^{9}$ At this stage of the migraine episode it is believed that nociceptive propagation is bolstered and extended by the release of CGRP and inflammatory mediators released from mast cells. Subsequent to this, sensitization and activation of central trigeminovascular neurons transpire over 30-60 minutes post peripheral nerve activation, reaching a maximum intensity after 2 hours. Central trigeminovascular activation is associated with severe cephalic muscle tenderness and sensitivity to touch. ${ }^{22}$

Last, as the brain homeostasis gradually returns to normal, resolution and pain relief is often accompanied by asthenia, i.e. loss of energy, somnolence, and concentration difficulty. ${ }^{23}$ Importantly, a symptomatic resolution phase is more characteristic of aura migraine than of non-aura migraine, and normally demonstrates a positive correlation with pain severity. ${ }^{23}$

\section{Four phases, multiple inputs}

Considering the four phases of migraine alluded to above, viz. sensitization and premonition, CSD and aura, headache, and resolution, the question can be raised as to which neurobiological factors may play a role in the initiation and propagation of nociceptive stimuli, as these may be current or future targets for therapeutic intervention. The answer to this question is complex and as such, only a brief overview will be provided.

During the last few decades, several significant advances have been made in our understanding of migraine. Historically, migraine was thought to be the result of dilating extracranial arteries and intracranial blood vessels that subsequently activated perivascular stretch receptors. ${ }^{24}$ In this regard for example, the $5 \mathrm{HT}_{1 \mathrm{~B} / \mathrm{D}}$ receptor agonists, i.e. 'triptans' have been developed as vasoconstrictors for the treatment of migraine. Today, however, we know that the triptans also act by means of their $5 \mathrm{HT}_{1 \mathrm{D}}$ and recently discovered $5 \mathrm{HT}_{1 \mathrm{~F}}$ receptor targets to modulate trigeminovascular neurons, while also reducing the release of CGRP. ${ }^{25}$ In this section we will provide a brief overview of the major targets of investigation in current migraine research.

\section{Neuropeptides}

Since the discovery of CGRP26 and PACAP, ${ }^{27}$ our understanding of the initiation and propagation of migraine pain has significantly broadened. In fact, the identification of these molecules, for the first time, sheds light on how triggers of migraine ultimately sensitise the trigeminal nociceptive pathway. This is important and valuable as we now have a better understanding of migraine as state of altered brain activity and nociceptive signalling, rather than being a condition of rapid vascular change.

Upon presentation with, or experience of a specific contextually relevant trigger, e.g. alcohol, caffeine, elevated oestrogen concentration, inflammation, or excessive stress, biological targets such as the transient receptor potential cation channel subfamilies A (TRPA1) and V (TRPV1) located in peripheral nociceptors are believed to be activated. ${ }^{21}$ Subsequently, CGRP is released to facilitate the propagation and intensity of trigeminovascular nociceptive transmission. In fact, CGRP is not only a potent vasodilator with proposed antiinflammatory action, ${ }^{28,29}$ it is also located in the afferents that innervate meningeal blood vessels. Moreover, CGRP has been shown to bolster glutamatergic neurotransmission and has been demonstrated to trigger migraine episodes in pain-free migraineurs, but not in healthy volunteers. ${ }^{30}$ This is significant as excessive glutamatergic signalling is associated with CSD, which is believed to underlie aura migraine. ${ }^{9}$ In addition, CGRP 
also facilitates substance $P$ release which may contribute to the hyperemia characteristic of the aura phase in migraine and intensifies signal transmission in the trigeminal ganglion, thereby contributing to the peripheral sensitization of trigeminal neurons. $^{31}$

The other neuropeptide that needs mentioning here is PACAP which, although demonstrating fluctuating levels both within and between migraineurs, ${ }^{32}$ has been demonstrated to modulate circadian rhythm, a physiological system closely related to migraine in some individuals. ${ }^{33}$ Indeed, it has been shown that inhibiting PACAP signalling via its $\mathrm{PAC}_{1}$ receptor has marked therapeutic potential in the treatment of migraine. ${ }^{27}$

Currently, investigations into the role neuropeptides play in processes of pain and central nervous system functioning are at the forefront of research. As relatively little is known about these molecules, the pathophysiological roles of neuropeptides, such as CGRP, PACAP and several others, e.g. orexins, oxytocin and neuropeptide $Y$, are continuously being studied as possible targets of intervention in the treatment of both migraine and other relevant conditions.

\section{Neurotransmitters}

Although a number of neurotransmitters, including noradrenalin and dopamine, have been implicated in the pathophysiology of migraine, emphasis will be placed on serotonin as this is the only neurotransmitter currently targeted by therapeutic intervention strategies. While glutamate also plays a major role in the pathophysiology of CSD and migraine, the effects of glutamate modulators, e.g. ketamine, are still being investigated. ${ }^{34}$ However, ketamine has been used as an abortive agent especially in migraine with aura. ${ }^{35}$ As indicated in Table 2, the anticonvulsants used as preventive treatment may also decrease glutamate neurotransmission. ${ }^{36}$

Since the development of the 'triptan' class of drugs, the involvement of serotonin in migraine has been believed to be restricted to its effect on extracranial and cranial vasoactive responses. ${ }^{37}$ Lately, however, the serotonergic system, originating in the raphe nuclei and innervating inter alia the basal ganglia, thalamus, cortex and the trigeminal ganglion, has been found to be intricately involved in the neural modulation of nociceptive signalling, independent of its actions on blood vessel responses. Initially migraine was proposed to be a condition characterised by low serotonergic activity with sudden increases during an episode. This hypothesis was based on findings that $5 \mathrm{HT}_{2 \mathrm{~A}}$ receptor antagonists, e.g. pizotifen and methysergide, are valuable prophylactics, while $5 \mathrm{HT}_{1 \mathrm{~B} / \mathrm{D}}$ agonists, which function via auto-receptor induced reductions in serotonin release, are useful during the acute pain phase of migraine..$^{38,39}$

Currently, though, our understanding of the role of serotonin in migraine involves a broader perspective in that it is now known that serotonin, depending on its concentration and the location of its specific receptors, is involved in the modulation of nociceptive pathways following trigeminal sensitization and that it can both inhibit or facilitate pain. ${ }^{40}$ In the central nervous system, serotonin mainly has an analgesic role as it inhibits nociceptive signal propagation from the peripheral to the central nociceptors. ${ }^{37}$ Therefore, low levels of central serotonin may disinhibit such nociceptive signals, resulting in excessive pain signalling. Serotonin also plays a significant and unique role in trigeminally sensitised migraineurs vs. non-sensitised controls in that low serotonin levels contribute to the hypersensitization often observed in the premonitory and aura phases of migraine episodes. Subsequently, sudden increases in serotonin release during the acute pain phase, contribute not to analgesia, but to pain via binding on its proalgesic $5 \mathrm{HT}_{2 \mathrm{~A}}$ receptors. ${ }^{41}$

In terms of the response of migraine pain to $5 \mathrm{HT}_{1 \mathrm{~B} / \mathrm{D}}$ agonists, e.g. sumatriptan, several mechanisms have been proposed. First, $5 \mathrm{HT}_{1 \mathrm{~B}}$ receptor stimulation results in extracranial, but not intracranial vasoconstriction, leading some to believe that the drug is incapable of crossing the blood-brain barrier; however, sumatriptan induces more central nervous system adverse effects compared to placebo intervention, which somewhat undermines this argument. ${ }^{37}$ Whether vasoconstriction in fact plays any role in its analgesic effects remains highly debatable. A more plausible explanation for the therapeutic benefit of $5 \mathrm{HT}_{1 \mathrm{~B} / \mathrm{D}}$ agonists in migraine is its modulation of nociceptive signalling via its actions on $5 \mathrm{HT}_{1 \mathrm{~B} / \mathrm{F}}$ receptors, independent of its actions on vasoactive processes. In fact, sumatriptan, but not aspirin, has been shown to suppress signalling between the trigeminal ganglion and the cortex which abrogates the cortical interpretation of pain, while selective $5 \mathrm{HT}_{1 \mathrm{~F}}$ receptor agonists, e.g. lasmidiptan, that exert these effects in the absence of any vasoactive action, are currently being developed. ${ }^{37}$

\section{Migraine treatment: From bench to evidence-based bedside}

Migraine is treated with respect to acute and prophylactic intervention, while successful treatment of an acute migraine attack is defined by the following criteria: ${ }^{42}$

- The patient must be pain-free after 2 hours;

- The headache must improve from moderate to severe to mild or none in 2 hours;

- Efficacy must be consistent in two out of every three attacks; and

- Headache should not be recurrent and no further drug intake within 24 hours after successful treatment should be necessary.

Drugs for acute episodes (Table 1) can be divided in nonspecific treatments such as paracetamol, non-steroidal anti-inflammatory drugs (including aspirin), opioids, and combinations of analgesics. These (except the opioids) usually constitute the first-line options for the treatment of mild to moderate migraine attacks. The second class of drugs indicated for acute intervention is the migraine-specific drugs (ergotamine tartrate and the triptans); these have historically been used only in 'severe' attacks, but given the intense and excruciating nature of most migraine episodes, these compounds enjoy significant favor among clinicians. ${ }^{43}$ With regard to the latter, triptans are preferred as first choice drugs and although ergotamine is very effective and demonstrates low relapse rates, its poor tolerability and relative risk of overuse headache (see Fact Box 1) rendered it to be preferred in a small group of migraineurs only, presenting with infrequent headaches of a long duration and complying 
with dosing restrictions. ${ }^{44}$ All in all, a stratified care approach, where drugs are selected according to the degree of disability, is preferred to a step care approach, where treatment is initialised with safe and low-cost drugs. ${ }^{45}$

Thegeneral principlesfor the prophylacticor preventivetreatment of migraine have been summarised in Table 2. Drugs from diverse pharmacological classes are effective, although current evidence and clinical experience favor the beta-adrenoceptor antagonists, valproic acid, topiramate, and amitriptyline as firstline drugs. In fact, evidence that supports the use of other drugs, e.g. the calcium channel blockers, i.e. verapamil and flunarizine, is not as robust. ${ }^{36}$ Although multiple mechanisms of action may be involved in the prevention of migraine, it is suggested that all of the indicated prophylactics either inhibit cortical excitation or restore nociceptive dysmodulation. The anticonvulsants (and calcium channel blockers) reduce neuronal hyperexcitability in which glutamate dysfunction may play an important role. ${ }^{36}$ Further, as alluded to earlier, descending nociceptive inhibition may be restored by drugs with actions on serotonergic $5 \mathrm{HT}_{1 \mathrm{~B} / \mathrm{D}}$ receptors. ${ }^{36}$

While most studies and clinical trials do not differentiate between the management of episodic migraine with aura (classic migraine) and migraine without aura (common migraine), there are indications that the efficacy of drugs may vary according to the presence of an aura, although this is an inadequately studied topic. ${ }^{35}$ In addition to the differential effects of sumatriptan in migraineurs presenting with and without aura (see Section 2), ${ }^{19}$ it has also been found that in classic migraine, lamotrigine, daily aspirin and flunarizine may generally be effective prophylactic agents, and magnesium, furosemide and ketamine effective acute interventions. ${ }^{35}$

Table 1: Treatment indicated for acute intervention in migraine episodes

\section{Acute treatment}

General Principles: ${ }^{46}$

- Administer at the onset of migraine (within 15 min of pain onset); ${ }^{47}$

- A large single dose tends to work better than repetitive small doses;

- Pretreatment with an antiemetic (metoclopramide, chlorpromazine, prochlorperazine) $15-30$ min before oral/non-oral migraine treatments is indicated if nausea and vomiting are severe;

- Metoclopramide also reverses migraine-induced gastric stasis and enhances absorption of oral medications;

- Overuse of all acute migraine therapies can cause medication overuse headache (see Fact Box 1); limit use of acute therapies to 2 or 3 days/week or to a maximum of 10 days/month; 48

- Emergency treatment of migraine currently utilises dopamine receptor antagonists, ketorolac, dexamethasone and IV fluid supplementation;

- The use of opioids is not recommended and has decreased ${ }^{49}$ (see paragraph 4.2)

\begin{tabular}{|c|c|c|c|}
\hline $\begin{array}{l}\text { Active ingredient and trade } \\
\text { name where applicable }\end{array}$ & $\begin{array}{l}\text { Dosage interval (if repeated) and } \\
\text { maximum daily dose }\end{array}$ & Pharmacokinetics & $\begin{array}{l}\text { Mechanism of action and general } \\
\text { comments }\end{array}$ \\
\hline
\end{tabular}

\begin{tabular}{|c|c|c|c|}
\hline \multicolumn{4}{|c|}{ Analgesics and Non-steroidal anti-inflammatory drugs } \\
\hline $\begin{array}{l}\text { Paracetamol } \\
\text { Panado and others }\end{array}$ & $1 \mathrm{~g}$ every 4 hours, max: $4 \mathrm{~g}^{50}$ & $\begin{array}{l}\mathrm{T}_{\max } 0.5-1 \text { hour } \\
\text { Elimination } \mathrm{t}_{1 / 2} 2 \text { hours }\end{array}$ & \multirow{5}{*}{$\begin{array}{l}\text { MOA: Inhibits PG synthesis and inhibit } \\
\text { neurogenically mediated inflammation in } \\
\text { the trigeminovascular system; } \\
\text { First-line treatment for mild to moderate } \\
\text { and even some severe attacks; } \\
\text { A combination of aspirin/ paracetamol/ } \\
\text { caffeine is effective with a high speed of } \\
\text { onset; } 52 \\
\text { All NSAIDs may be effective in treating } \\
\text { migraine with/without aura and the } \\
\text { failure of one does not exclude the use of } \\
\text { another. }\end{array}$} \\
\hline $\begin{array}{l}\text { Aspirin } \\
\text { Disprin', Ecotrin, Dr. du Toit's pain } \\
\text { expeller, Myoprin and others }\end{array}$ & $\begin{array}{l}975-1000 \text { mg every } 4-6 \text { hours, } \\
\text { max } 5.4 \mathrm{~g} \text { (varies depending on } \\
\text { indication) })^{53}\end{array}$ & $\begin{array}{l}\mathrm{T}_{\max } 1-2 \text { hours } \\
\text { Elimination } \mathrm{t}_{1 / 2} \text { salicylate active } \\
\text { metabolite } 5-6 \text { hours }^{51}\end{array}$ & \\
\hline $\begin{array}{l}\text { Ibuprofen } \\
\text { Brufen;, Nurofen and others }\end{array}$ & $\begin{array}{l}400 \text { mg every } 4 \text { hours, max } \\
2400 \text { mg }^{54}\end{array}$ & $\begin{array}{l}\mathrm{T}_{\max } 1-2 \text { hours } \\
\text { Elimination } t_{1 / 2} 2 \text { hours }{ }^{51}\end{array}$ & \\
\hline $\begin{array}{l}\text { Diclofenac } \\
\text { Voltaren', Diclofenac Biotech, } \\
\text { Mylan Diclofenac and others } \\
\text { Diclofenac powder } \\
\text { Cataflam and Catafast }\end{array}$ & $\begin{array}{l}50 \mathrm{mg} 3 \text { - } 4 \text { times per day, max } \\
150 \mathrm{mg} \\
50 \mathrm{mg} \text { single dose } \mathrm{e}^{51,55}\end{array}$ & $\begin{array}{l}\mathrm{T}_{\max }<1 \text { hour } \\
\text { Elimination } \mathrm{t}_{1 / 2} 2 \text { hours }\end{array}$ & \\
\hline $\begin{array}{l}\text { Naproxen } \\
\text { Synflex: Aleve', Nafasol }{ }^{\circledR} \text { and } \\
\text { others }\end{array}$ & $\begin{array}{l}500 \mathrm{mg} \text { orally/ rectally } \\
\text { (although not clinically useful } \\
\text { as monotherapy) }{ }^{56} 500-550 \mathrm{mg} \\
\text { twice a day, } \max 1375 \mathrm{mg}\end{array}$ & $\begin{array}{l}T_{\max } 2 \text { hours } \\
\text { Elimination } t_{1 / 2} 14 \text { hours }\end{array}$ & \\
\hline
\end{tabular}

\section{Ergot alkaloids: Ergotamine tartrate tablets}

Ergotamine tartrate $1 \mathrm{mg} /$ Caffeine $100 \mathrm{mg}$ Cafergot $^{\circledast}$

Ergotamine tartrate $2 \mathrm{mg} /$ caffeine hydrate $100 \mathrm{mg} /$ Cyclizine hydrochloride 50mg Migril $^{\circledR}$
Elimination $t_{1 / 2} 2$ hours, duration of action much longer. Caffeine increases absorption and increases plasma peak levels ${ }^{44}$
- MOA: Agonist on a, DA and 5-HT $\mathrm{H}_{1 \mathrm{~B} / 1 \mathrm{D}}$ receptors; causes vasoconstriction of intracranial vessels and blocks the trigeminovascular pathway centrally; ${ }^{44}$ $\mathrm{mg}$ in 24 hours. Total dose in any 7 days should not exceed $10 \mathrm{mg}$

- Contraindicated in vascular diseases, sepsis, uncontrolled hypertension, hepatic/ renal dysfunction, porphyria, pregnancy; ${ }^{44}$

- Nausea and vomiting in $\pm 10 \%$ patients, weakness, numbness and tingling of extremities, angina pain, brady/ tachycardia, ergotism; ${ }^{44}$

- Ergotamine and triptans should not be used within 24 hours of each other; ${ }^{46}$

- Metabolized by CYP450, concomitant use with CYP450 inhibitors may cause ergotism $^{44}$ 


\begin{tabular}{|c|c|c|c|}
\hline \multicolumn{4}{|c|}{$5-\mathrm{HT}_{1 \mathrm{~B} / \mathrm{D}}$ agonists } \\
\hline $\begin{array}{l}\text { Sumatriptan } \\
\text { Imigran } 50 \text { and } 100 \mathrm{mg} \\
\text { tablets, injection } 6 \mathrm{mg} / 0.5 \mathrm{ml} \\
\text { in a prefilled syringe and nasal } \\
\text { spray } 20 \mathrm{mg} / 0.1 \mathrm{ml} \text { in a unit- } \\
\text { dose device. } \\
\text { Migrex, Triptam } \\
50 \text { and } 100 \mathrm{mg}^{\circ} \text { tablets }\end{array}$ & $\begin{array}{l}\text { Oral: initially } 50 \text { - } 100 \mathrm{mg} \text {, dose } \\
\text { may be repeated after } 2 \text { - } 4 \text { hours } \\
\text { if symptoms recur, max } 300 \mathrm{mg} / \\
24 \text { hours } \\
\text { Sc: } 6 \text { mg, may be repeated after } \\
\text { at least } 1 \text { hour, max } 12 \mathrm{mg} / \\
24 \text { hours } \\
\text { Intranasal } 20 \text { mg, may be } \\
\text { repeated after } 2 \text { hours, max } \\
40 \text { mg / } 24 \text { hours }\end{array}$ & $\begin{array}{l}\text { Elimination } t_{1 / 2} 2 \text { hours } \\
\text { Onset of action } 10 \mathrm{~min} \text { (s.c.), and } \\
30 \mathrm{~min} \text { (oral) } \\
\text { Extensively metabolised in liver. }\end{array}$ & $\begin{array}{l}\text { MOA Selective } 5 \mathrm{HT}_{1 \mathrm{~B} / \mathrm{D}} \text { receptor } \\
\text { agonists. Normalization of dilated } \\
\text { intracranial arteries, inhibition of } \\
\text { vasoactive peptide release, }{ }^{25} \text { and } \\
\text { inhibition of transmission through } \\
\text { second-order neurons ascending to the } \\
\text { thalamus; }{ }^{46} \\
\text { - First-line therapy for mild to severe } \\
\text { migraine and when rescue therapy } \\
\text { with nonspecific medications are }\end{array}$ \\
\hline $\begin{array}{l}\text { Naratriptan } \\
\text { Naramig }^{\circ} \\
2.5 \text { mg tablets }^{\circ}\end{array}$ & $\begin{array}{l}\text { May be repeated once after } \\
4 \text { hours if needed. Max } 5 \mathrm{mg} / \\
24 \text { hours } \\
\text { Hepatic and renal impairment: } \\
\max 2.5 \mathrm{mg} / 24 \text { hours }\end{array}$ & $\begin{array}{l}\text { Slower onset of action, longer } \\
t_{1 / 2}(6 \text { hours })^{60} \text {; less headache } \\
\text { recurrence; may be used for } \\
\text { a few days continuously for } \\
\text { menstrual migraine, beginning } 2 \\
\text { days ahead of menstrual period }{ }^{61}\end{array}$ & $\begin{array}{l}\text { ineffective; } \\
\text { - All triptans may be readministered } \\
\text { within } 2 \text { hours as needed if recurrence } \\
\text { of headache occur with a maximum of } \\
\text { two doses daily; } \\
\text { - Although different formulations of } \\
\text { a specific triptan may be used in the }\end{array}$ \\
\hline $\begin{array}{l}\text { Eletriptan } \\
\text { Relpax } \\
40 \text { and } 80 \text { mg tablets }\end{array}$ & Max: 160 mg / 24 hours & $\begin{array}{l}\text { Eletriptan is contraindicated with } \\
\text { CYP450 3A4 inhibitors }{ }^{59}\end{array}$ & $\begin{array}{l}\text { same 24-hour period, only one triptan } \\
\text { may be used during this time frame; } \\
\text { - Triptans should not be used for more }\end{array}$ \\
\hline $\begin{array}{l}\text { Rizatriptan } \\
\text { Maxalt } \\
5 \text { and } 10 \text { mg tablets; } \\
10 \text { mg wafers }\end{array}$ & Max 30mg / 24 hours & & $\begin{array}{l}\text { than } 3 \text { days of any given week due to } \\
\text { the risk of overuse headache; } \\
\text { - Sumatriptan, rizatriptan and } \\
\text { zolmitriptan should not be given within }\end{array}$ \\
\hline $\begin{array}{l}\text { Zolmitriptan } \\
\text { Zomig }^{\circ} \\
2.5 \mathrm{mg} \text { tablets and dispersible } \\
\text { tablets }\end{array}$ & Max $15 \mathrm{mg} / 24$ hours & $\begin{array}{l}\text { Elimination } t_{1 / 2} 3 \text { hours }^{62} \\
2.5 \text { mg three times per day for } \\
\text { menstrual migraine prophylaxis }\end{array}$ & $\begin{array}{l}2 \text { weeks of MAOI therapy; } \\
\text { - Concomitant SSRIs may cause } \\
\text { serotonin syndrome, although the } \\
\text { risk is very low and reconsideration } \\
\text { of this FDA warning in } 2006 \text { is } \\
\text { recommended; } 58 \\
\text { - Side effects: paresthesia, fatigue, } \\
\text { dizziness, flushing, warm sensations, } \\
\text { and somnolence. "Triptan sensations," } \\
\text { e.g. tightness, heaviness, or pain in the } \\
\text { chest, neck, or throat are reported by } \\
25 \% \text { of patients; } \\
\text { - Contraindicated in a history of ischemic } \\
\text { heart disease and cerebrovascular } \\
\text { disease. Patients at risk for } \\
\text { unrecognized coronary artery disease } \\
\text { should use triptans with caution; } 59 \\
\text { - Triptans have traditionally been } \\
\text { contraindicated in hemiplegic migraine } \\
\text { and migraine with brain stem aura; } \\
\text { however, this prohibition is being } \\
\text { reconsidered as it is evidently safe to } \\
\text { use in these conditions } 35\end{array}$ \\
\hline
\end{tabular}

\section{Preventive (prophylactic therapy)}

\section{General principles: ${ }^{46}$}

- Consider if frequent attacks require acute medication more than twice per week, the duration of an attack is longer than 24 hours, in case of medication failure or overuse and in uncommon migraine variants with the risk for permanent neurologic injury;

- Administer daily to reduce the frequency, severity, and duration of attacks and to increase response to acute therapy;

- May be given as intermittent therapy when headaches recur in a predictable pattern (e.g. exercise-induced/menstrual migraine);

- Drug selection is primarily based on the side effect profiles and comorbid conditions; response is unpredictable and a 2-3 month trial is necessary to achieve benefit, while maximal benefit is typically observed following 6 months of treatment; ${ }^{59}$

- Start with low doses, titrate until therapeutic effect or side-effects become intolerable;

- Overuse of acute headache treatments will interfere with the effects of preventive treatment; 59

- Continue prophylaxis for at least 6-12 months after headache frequency and severity have diminished, gradually taper or discontinue;

- Propranolol, timolol, divalproex sodium, topiramate, as well as Botulinum toxin serotype A (BoNT-A) and CGRP-antagonists are the only FDA approved prophylactic agents, ${ }^{63,64}$ while numerous other drugs from diverse pharmacological classes have also been used successfully (see below).

\begin{tabular}{lccc}
$\begin{array}{l}\text { Active ingredient and trade } \\
\text { name where applicable }\end{array}$ & Dosage interval & Mechanism of action & General comments \\
\hline & & Beta adrenergic blockers & \\
\hline $\begin{array}{l}\text { Propranolol } \\
\text { Inderal and others } \\
\text { (Also timolol, metoprolol, } \\
\text { atenolol and nadolol) }\end{array}$ & $40-80 \mathrm{mg} \mathrm{bd}$ & $\begin{array}{l}\text { Restore descending } \\
\text { nociceptive inhibition }\end{array}$ & Reduce the frequency of migraine attacks by \\
\end{tabular}




\begin{tabular}{|c|c|c|c|}
\hline \multicolumn{4}{|c|}{ Anticonvulsants } \\
\hline $\begin{array}{l}\text { Valproic acid } \\
\text { Convulex }^{\circledast}, \text { Epilim }^{\circledast} \text { and others }\end{array}$ & $\begin{array}{l}300 \mathrm{mg} / \mathrm{d} \text {, titrate slowly } \\
\text { upwards to } 600-900 \mathrm{mg} / \mathrm{d}\end{array}$ & $\begin{array}{l}\text { Reduce neuronal } \\
\text { hyperexcitability }\end{array}$ & $\begin{array}{l}\text { Side-effects include nausea, tremor, } \\
\text { somnolence, weight gain, hair loss, } \\
\text { hepatotoxicity; } \\
\text { Baseline liver function tests are required. }\end{array}$ \\
\hline $\begin{array}{l}\text { Topiramate } \\
\text { Topamax }^{\circledast}, \text { Epimate }^{\circledast}, \text { Epitoz }^{\circledast}, \\
\text { Topirol }^{\circledR} \text { and others }\end{array}$ & $50-200 \mathrm{mg} / \mathrm{d}$ & $\begin{array}{l}\text { AMPA/ kainate glutamate } \\
\text { antagonist, blocks neuronal } \\
\text { excitability }\end{array}$ & $\begin{array}{l}50 \% \text { of patients respond; }{ }^{46} \\
\text { Side-effects include paresthesia, dizziness, } \\
\text { fatigue, anorexia, somnolence, memory } \\
\text { impairment }\end{array}$ \\
\hline \multicolumn{4}{|c|}{ Antidepressants } \\
\hline 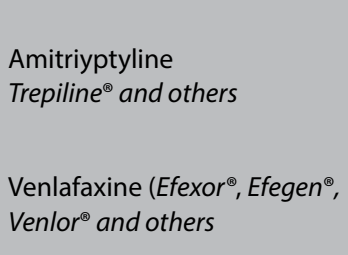 & $\begin{array}{l}10-25 \mathrm{mg} \text { at night, seldom }> \\
75-100 \mathrm{mg} \text { necessary }\end{array}$ & $\begin{array}{l}\text { Effects are independent } \\
\text { of antidepressant activity, } \\
\text { probably related to down } \\
\text { regulation of central } 5-\mathrm{HT}_{2 \mathrm{~A}} \\
\text { receptors, increased synaptic } \\
\text { noradrenaline and enhanced } \\
\text { opioid receptor actions }{ }^{46}\end{array}$ & $\begin{array}{l}\text { Anticholinergic effects may limit use } \\
\text { especially elderly, increased appetite and } \\
\text { weight gain, cardiovascular effects; } \\
\text { Good tolerability, nausea, palpitations }{ }^{65}\end{array}$ \\
\hline $\begin{array}{l}\text { Flunarizine } \\
\text { Sibelium }^{\circledast} \text { and others }\end{array}$ & $5-10 \mathrm{mg}$ at night ${ }^{67}$ & $\begin{array}{l}\text { Calcium channel blocker } \\
\text { reduces neuronal } \\
\text { hyperexcitability; also } \\
\text { dopamine, serotonin } \\
\text { and histamine receptor } \\
\text { antagonist }^{68}\end{array}$ & $\begin{array}{l}\text { If no improvement after } 2 \text { months, } \\
\text { discontinue use; Should be interrupted } \\
\text { after } 6 \text { months and only reinstated if patient } \\
\text { relapses; }{ }^{67} \\
\text { Side-effects include weight gain, fatigue and } \\
\text { mood changes }^{68}\end{array}$ \\
\hline $\begin{array}{l}\text { Pizotifen } \\
\text { Sandomigran }^{\circledast}\end{array}$ & $\begin{array}{l}0.5-3 \mathrm{mg} / \mathrm{d} \text {, max single dose } \\
3 \mathrm{mg} \text {, max daily dose } 4.5 \mathrm{mg}\end{array}$ & $\begin{array}{l}\text { Histamine and serotonin } \\
\text { receptor antagonist; weak } \\
\text { anticholinergic }\end{array}$ & Drowsiness and weight gain ${ }^{69}$ \\
\hline $\begin{array}{l}\text { Clonidine } \\
\text { Dixarit }^{\circledast}, \text { Menograin }^{\circledR}\end{array}$ & $\begin{array}{l}25 \text { microgram bd, increase up } \\
\text { to total of } 150 \text { micrograms/d in } \\
\text { divided doses }\end{array}$ & Alpha 2 adrenoceptor agonist & $\begin{array}{l}\text { Withdraw gradually to prevent rebound } \\
\text { hypertension; Evidence of lack of efficacy in } \\
\text { migraine prophylaxis }{ }^{70}\end{array}$ \\
\hline
\end{tabular}

Fact Box 1 - Medication overuse headache

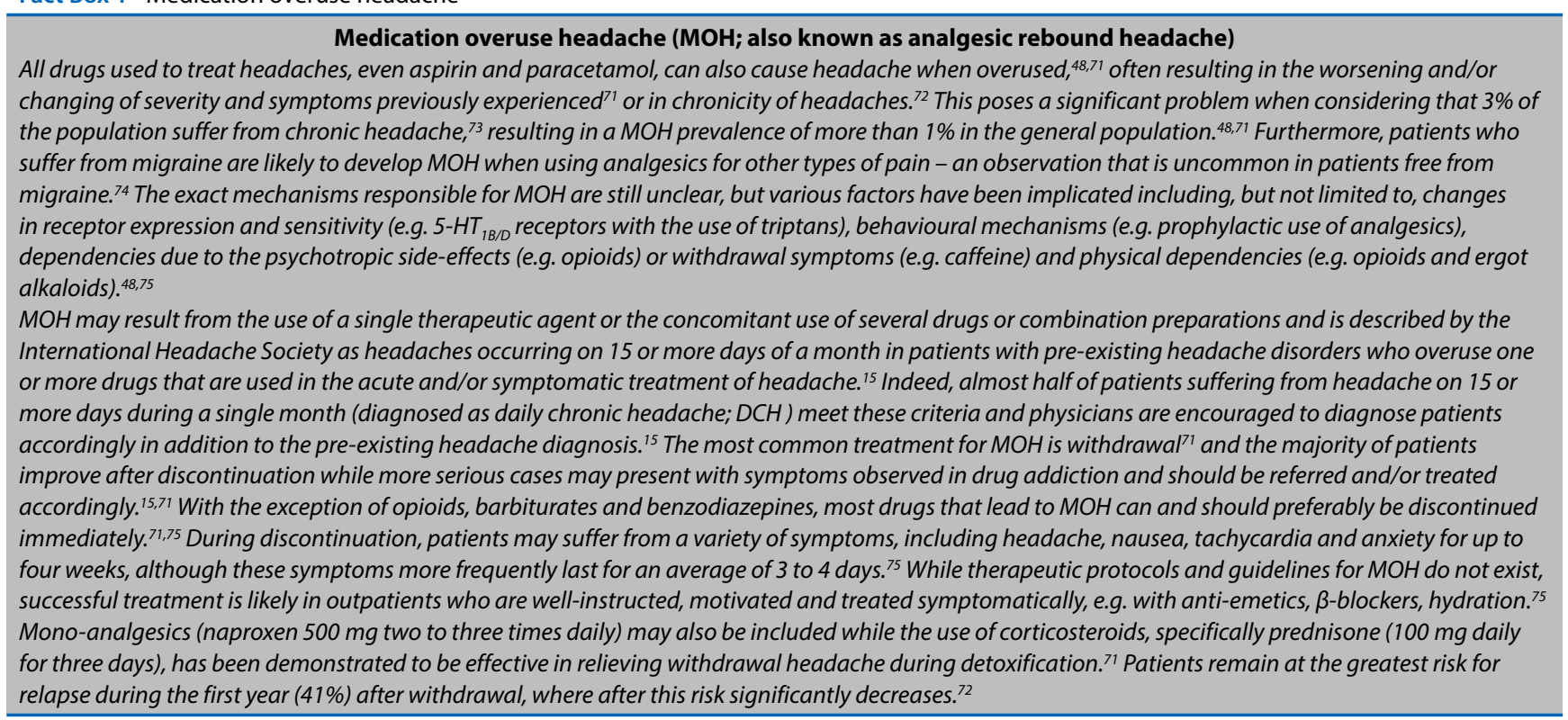

\section{Novel drugs for migraine prophylaxis (FDA-approved, but not registered in SA for the indication)}

\section{Botulinum toxin type A (BoNT-A; Botox ${ }^{\oplus}$; Onabotulinumtoxin A)}

Botulinum toxin type A (BoNT-A) is an FDA-approved treatment (2010) for the prevention of chronic migraine in adults older than 18 years. ${ }^{76}$ It has been demonstrated to be effective and safe by data from Phase III of the Research Evaluating Migraine Prophylaxis Therapy-program (PREEMPT). ${ }^{63}$ Treatment response, however, varies greatly among patients ${ }^{77}$ and therefore patient selection is crucial; this in turn depends on the site and frequency of pain, among others. ${ }^{63}$ Longer term treatments seem to increase its efficacy, ${ }^{63}$ and while current guidelines recommend a cessation of treatment following 2 cycles in patients not responding to a single cycle of treatment, such early cessation may not be justified. It appears as though its benefit increases with additional treatment cycles, with 5 cycles of treatment sometimes being necessary to reach optimal effect. ${ }^{77}$ In responders, one BoNT-A treatment can be effective for approximately 3 months. BoNT-A not only inhibits the release of acetylcholine from presynaptic nerve endings, but may also modify the release of transmitters involved in pain transmission, 
e.g. substance $\mathrm{P}^{78}$ and $\mathrm{CGRP}^{79}$ thereby preventing activation of central pain networks. Furthermore, BoNT-A is well tolerated and injection-related side effects are usually mild and transient with little or no systemic side effects. ${ }^{80}$

\section{CGRP antagonists}

As alluded to earlier, CGRP is a vasoactive peptide released from activated trigeminal nerves which facilitates pain transmission from cerebral vessels to the central nervous system..$^{81}$ In realization of the role CGRP plays in the pathophysiology of migraine, a range of monoclonal antibodies have recently been developed, including erenumab (Aimovig ; 2018), fremanezumab (AJOVY; 2018), and galcanezumab (Emgality"; 2018). While erenumab targets the CGRP receptor, fremanezumab, galcanezumab and eptinezumab (still under regulatory review) bind and inactivate the CGRP molecule itself. The short-term side-effects of these drugs have been minimal and were mostly restricted to injection site reactions. ${ }^{64}$ However, fremanezumab, but not erenumab, may carry a risk for more severe hypersensitivity reactions, while general concern is expressed for possible longterm cardiovascular sequelae. These antibodies are usually self-administered once a month as a single subcutaneous injection. As may be expected, they are relatively expensive (approximately US\$ 575/month) and patients would have to fail on treatment with at least two to three oral preventive drugs to become eligible for such treatment. While currently available preventive drugs offer relatively limited efficacy and are not free from side effects, CGRP monoclonal antibodies may offer hope to many migraine sufferers that remain unresponsive to current interventions.

\section{Emergency treatment of migraine}

When failing on customary acute migraine treatment (Table 1), patients may present to the emergency room during which time parenteral treatment is usually preferred. Recommendations for emergency treatment were compiled by the American Headache Society ${ }^{70}$ following a systematic review of clinical trials and a meta-analysis that included the following:

- Antidopaminergic drugs (metoclopramide, prochlorpromazine, haloperidol, and droperidol are commonly used) do not only relieve nausea, vomiting and gastroparesis associated with acute migraine, but are also analgesic, albeit for reasons still unknown. Akathisia (restlessness) and dystonic reactions may occur in as much as a third of patients receiving intravenous dopamine antagonists and to prevent this, intravenous diphenhydramine is often added; however, this practice is not supported by all clinicians.

- Subcutaneous sumatriptan is also effective although side effects include flushing, chest pain, and an occasional worsening of headache symptoms. Further, a higher incidence of headache recurrence within 24 hours is also noted. In general, antidopaminergic agents are usually better tolerated than sumatriptan.

- Nonsteroidal antiinflammatory drugs, e.g. ketorolac and naproxen, alone or in combination with the antidopaminergics or sumatriptan may be of benefit.
- Antihistamines (monotherapy), ketamine, magnesium and propofol have not been found particularly effective.

- Dexamethasone (10 mg IVI) can be added to counter the recurrence of headaches-which patients often experience within 24 hours of visiting the emergency department-but be mindful of giving steroids to patients with diabetes.

- Slow administration of parental drugs is necessary and may prevent some of the commonly reported adverse effects.

- While opioids were previously the mainstay of abortive treatment of acute migraine episodes, it is now recommended that they best be avoided due to the lack of evidence regarding their efficacy and possible long-term sequelae. ${ }^{82}$ In this regard, the decline in use of the emergency room opioids has also decreased the recurrence rate of acute episodes that would otherwise have necessitated more visits to an emergency care setting. ${ }^{49}$

\section{Conclusion}

Migraine is a severe, debilitating and highly disabling condition that is founded in an altered state of brain function that results in a hypersensitive interpretation of sensory stimuli and exacerbated trigeminovascular nociceptive pain transmission. The condition is variably characterised by four phases, i.e. a premonitory phase, CSD and aura, acute headache and finally, resolution. Further, aura migraine may be associated with significant comorbidities related to epilepsy, ischemic stroke and cardiovascular pathology and should be regarded not only as a risk factor, but as a unique neurobiological disturbance.

\section{References}

1. Silberstein SD, et al. The International Classification of Headache Disorders, (ICHD-II) - Revision of Criteria for 8.2 Medication-Overuse Headache. Cephalalgia. 2005;25(6):460-5.

2. Jackson J, et al. A comparative effectiveness meta-analysis of drugs for the prophylaxis of migraine headache. PloS one. 2015;10(7):e0130733.

3. Dahlöf $C$, Dimenäs E. Migraine patients experience poorer subjective well-being/ quality of life even between attacks. Cephalalgia. 1995;15(1):31-6.

4. Lipton RB, Hamelsky SW, Dayno JM. What do patients with migraine want from acute migraine treatment? Headache: The Journal of Head and Face Pain. 2002;42:3-9.

5. Leonardi M, Raggi A. Burden of migraine: international perspectives. J Neurol Sci. 2013;34(1):117-8.

6. Hou $M$, et al. The effect and safety of monoclonal antibodies to calcitonin gene-related peptide and its receptor on migraine: a systematic review and meta-analysis. J Headache Pain. 2017;18(1):42.

7. Sheikh HU, et al. Risk of stroke associated with use of estrogen containing contraceptives in women with migraine: a systematic review. Headache: The Journal of Head and Face Pain. 2018;58(1):5-21.

8. Mainieri $G$, et al. Headache in epilepsy: prevalence and clinical features. J Headache Pain. 2015;16(1):72.

9. Dodick DW. A Phase-by-Phase Review of Migraine Pathophysiology. Headache: The Journal of Head and Face Pain. 2018;58:4-16.

10. Giffin $\mathrm{N}$, et al. Premonitory symptoms in migraine An electronic diary study. Neurology. 2003;60(6):935-40.

11. Burstein R, Noseda R, Borsook D. Migraine: multiple processes, complex pathophysiology. J Neurosci. 2015;35(17):6619-29.

12. Burstein $R$, Jakubowski $M$. Unitary hypothesis for multiple triggers of the pain and strain of migraine. J Comp Neurol. 2005;493(1):9-14.

13. Noseda $R$, et al. Neurochemical pathways that converge on thalamic trigeminovascular neurons: potential substrate for modulation of migraine by sleep, food intake, stress and anxiety. PLoS One. 2014;9(8):e103929. 
14. Pietrobon D, Moskowitz MA. Pathophysiology of migraine. Annu Rev Physiol. 2013;75:365-91.

15. Society HCCotlH. The international classification of headache disorders, (beta version). Cephalalgia. 2013;33(9):629-808.

16. Charles A, Hansen JM. Migraine aura: new ideas about cause, classification, and clinical significance. Curr Opin Neurol. 2015;28(3):255-60.

17. Dreier JP, et al. How spreading depolarization can be the pathophysiological correlate of both migraine aura and stroke, in Neurovascular Events After Subarachnoid Hemorrhage. Springer; 2015, p. 137-140.

18. Evans RW. The clinical features of migraine with and without aura. Pract Neurol. 2014;13:26-32.

19. Ward TN. Does the presence of aura inform us regarding migraine severity and response to treatment? AAN Enterprises; 2015.

20. Bartsch T, Goadsby P. Anatomy and physiology of pain referral patterns in primary and cervicogenic headache disorders. Headache Currents. 2005;2(2):42-8.

21. Borkum JM. Migraine triggers and oxidative stress: a narrative review and synthesis. Headache: The Journal of Head and Face Pain. 2016;56(1):12-35.

22. Bigal ME, Lipton RB. Clinical course in migraine conceptualizing migraine transformation. Neurology. 2008;71(11):848-55.

23. Quintela $E$, et al. Premonitory and resolution symptoms in migraine: a prospective study in 100 unselected patients. Cephalalgia. 2006;26(9):1051-60.

24. Graham J, Wolff HG. Mechanism of migraine headache and action of ergotamine tartrate. Arch Neurol Psychiatry. 1938;39(4):737-63.

25. Juhasz $G$, et al. Sumatriptan Causes Parallel Decrease in Plasma Calcitonin Gene-Related Peptide (CGRP) Concentration and Migraine Headache During Nitroglycerin Induced Migraine Attack. Cephalalgia. 2005;25(3):179-83.

26. lyengar S, Ossipov MH, Johnson KW. The role of calcitonin gene-related peptide in peripheral and central pain mechanisms including migraine. Pain. 2017;158(4):543

27. Vollesen ALH, Amin FM, Ashina M. Targeted pituitary adenylate cyclaseactivating peptide therapies for migraine. Neurotherapeutics. 2018:1-6.

28. Burgos-Vega C, Moy J, Dussor G. Meningeal afferent signaling and the pathophysiology of migraine; in Progress in Molecular Biology and Translational Science. Elsevier; 2015, p. 537-64.

29. Farello $G$, et al. The link between obesity and migraine in childhood: a systematic review. Ital J Pediatr. 2017;43(1):27.

30. Lassen L, et al. CGRP may play a causative role in migraine. Cephalalgia. 2002;22(1):54-61.

31. Thalakoti $S$, et al. Neuron-glia signaling in trigeminal ganglion: implications for migraine pathology. Headache: The Journal of Head and Face Pain. 2007;47(7):1008-23.

32. Akerman S, Goadsby PJ. Neuronal Pac: Relevance to migraine1: Relevance to migraine receptors mediate delayed activation and sensitization of trigeminocervical neurons: Relevance to migraine. Sci Transl Med. 2015;7(308):308ra157.

33. Holland PR, Barloese M, Fahrenkrug J. PACAP in hypothalamic regulation of sleep and circadian rhythm: importance for headache. J Headache Pain. 2018;19(1):20.

34. Goadsby PJ, Holland PR. Migraine Therapy: Current Approaches and New Horizons. Springer; 2018.

35. Vgontzas A, Burch R. Episodic Migraine With and Without Aura: Key Differences and Implications for Pathophysiology, Management, and Assessing Risks. Curr Pain Headache Rep. 2018;22(12):78.

36. Ramadan NM. Current Trends in Migraine Prophylaxis. Headache: The Journal of Head and Face Pain. 2007;47(s1):S52-S57.

37. Deen $M$, et al. Serotonergic mechanisms in the migraine brain-a systematic review. Cephalalgia. 2017;37(3):251-64.

38. Saxena PR, Ferrari MD. From serotonin receptor classification to the antimigraine drug sumatriptan. Cephalalgia. 1992;12(4):187-96.

39. Humphrey P. 5-Hydroxytryptamine and the pathophysiology of migraine. J Neurol. 1991;238(1):S38-S44.

40. Olesen J, et al. Origin of pain in migraine: evidence for peripheral sensitisation. Lancet Neurol. 2009;8(7):679-90.

41. Sommer C. Is serotonin hyperalgesic or analgesic? Curr Pain Headache Rep. 2006;10(2):101-6.

42. Evers $S$, et al. EFNS guideline on the drug treatment of migraine - revised report of an EFNS task force. Eur J Neurol. 2009;16(9):968-81.
43. Antonaci $F$, et al. A review of current European treatment guidelines for migraine. J Headache Pain. 2010;11(1):13-19.

44. Tfelt-Hansen $P$, et al. Ergotamine in the acute treatment of migraine: A review and European consensus. Brain. 2000;123(1):9-18.

45. Lipton RB, et al. Stratified care vs step care strategies for migraine: The disability in strategies of care (disc) study:a randomized trial. JAMA 2000;284(20):2599-605.

46. Wells BG, et al. Headache: Migraine and Tension-Type, in Pharmacotherapy Quick Guide. McGraw-Hill Education: New York, NY; 2017.

47. Matchar DB. Acute management of migraine: Highlights of the US Headache Consortium. Neurology. 2003;60(7):S21-S23.

48. Diener H-C, Limmroth V. Medication-overuse headache: a worldwide problem. Lancet Neurol. 2004;3(8):475-83.

49. Ruzek M, et al. ED treatment of migraine patients has changed. Am J Emerg Med. 2018.

50. Derry S, Moore RA. Paracetamol (acetaminophen) with or without an antiemetic for acute migraine headaches in adults. Cochrane Database Syst Rev. 2013;4.

51. Becker WJ. Acute Migraine Treatment in Adults. Headache: The Journal of Head and Face Pain. 2015;55(6):778-93.

52. Goldstein J, et al. Acetaminophen, Aspirin, and Caffeine in Combination Versus Ibuprofen for Acute Migraine: Results From a Multicenter, Double-Blind, Randomized, Parallel-Group, Single-Dose, Placebo-Controlled Study. Headache: The Journal of Head and Face Pain. 2006;46(3):444-53.

53. Kirthi $V$, et al. Aspirin with or without an antiemetic for acute migraine headaches in adults. Cochrane Database Syst Rev. 2010;4:CD008041-CD008041.

54. Rabbie R, Derry S, Moore RA. Ibuprofen with or without an antiemetic for acute migraine headaches in adults. Cochrane Database Syst Rev. 2013;4.

55. Derry S, Rabbie R, Moore RA. Diclofenac with or without an antiemetic for acute migraine headaches in adults. Cochrane Database Syst Rev. 2013;4.

56. Law S, Derry S, Moore RA. Naproxen with or without an antiemetic for acute migraine headaches in adults. Cochrane Database Syst Rev. 2013;10.

57. Limmroth V, et al. Features of medication overuse headache following overuse of different acute headache drugs. Neurology. 2002;59(7):1011-4.

58. Orlova Y, Rizzoli P, Loder E. Association of coprescription of triptan antimigraine drugs and selective serotonin reuptake inhibitor or selective norepinephrine reuptake inhibitor antidepressants with serotonin syndrome. JAMA Neurol. 2018;75(5):566-72.

59. Minor DS, Wofford MR. Chapter 45. Headache Disorders; in Pharmacotherapy: A Pathophysiologic Approach, 9e, DiPiro JT, et al. (Eds). The McGraw-Hill Companies: New York, NY; 2014.

60. Mannix LK, et al. Efficacy and tolerability of naratriptan for short-term prevention of menstrually related migraine: Data from two randomized, double-blind placebo-controlled studies. Headache: The Journal of Head and Face Pain. 2007;47(7):1037-49.

61. Newman L, et al. Naratriptan as Short-Term Prophylaxis of Menstrually Associated Migraine: A Randomized, Double-Blind, Placebo-Controlled Study. Headache: The Journal of Head and Face Pain. 2001;41(3):248-56.

62. Lionetto $L$, et al. Pharmacokinetic evaluation of zolmitriptan for the treatment of migraines. Expert Opin Drug Metab Toxicol. 2012;8(8):1043-50.

63. Barbanti P, Ferroni P. Onabotulinum toxin $A$ in the treatment of chronic migraine: patient selection and special considerations. J Pain Res. 2017;10:2319-29.

64. Goadsby PJ, et al. A controlled trial of erenumab for episodic migraine. New Eng J Med. 2017;377(22):2123-32

65. Bulut $S$, et al. Venlafaxine versus amitriptyline in the prophylactic treatment of migraine: randomized, double-blind, crossover study. Clin Neurol Neurosurg. 2004;107(1):44-8.

66. Ozyalcin SN, et al. The Efficacy and Safety of Venlafaxine in the Prophylaxis of Migraine. Headache: The Journal of Head and Face Pain. 2005;45(2):144-52.

67. Diener $\mathrm{H}$, et al. Efficacy and tolerability in migraine prophylaxis of flunarizine in reduced doses: a comparison with propranolol $160 \mathrm{mg}$ daily. Cephalalgia. 2002;22(3):209-21.

68. Karsan $\mathrm{N}$, et al. Flunarizine in migraine-related headache prevention: results from 200 patients treated in the UK. Eur J Neurol. 2018;25(6):811-7.

69. Crowder D, Maclay WP. Pizotif en once daily in the prophylaxis of migraine: results of a multi-centre general practice study. Curr Med Opin Res. 1984;9(4):280-5.

For a full list of reference please see http://www.safpj.co.za/ 
70. Snow V, et al. PHarmacologic management of acute attacks of migraine and prevention of migraine headache. Ann Intern Med. 2002;137(10):840-9.

71. Negro A, Martelletti P. Chronic migraine plus medication overuse headache: two entities or not? J Headache Pain. 2011;12(6):593-601.

72. Katsarava Z, et al. Medication Overuse Headache: Rates and Predictors for Relapse in a 4-year Prospective Study. Cephalalgia. 2005;25(1):12-5.

73. Stovner LJ, et al. The global burden of headache: a documentation of headache prevalence and disability worldwide. Cephalalgia. 2007;27(3):193-210.

74. Anish B, et al. Does Chronic Daily Headache Arise De Novo in Association With Regular Use of Analgesics? Headache: The Journal of Head and Face Pain. 2003;43(3):179-90.

75. Obermann M, Katsarava Z. Management of medication-overuse headache. Expert Rev Neurother. 2007;7(9):1145-55.

76. Rizzoli P, Mullally WJ. Headache. Am J Med. 2018;131(1):17-24.
77. Sarchielli P, et al. Stopping Onabotulinum Treatment after the First Two Cycles Might Not Be Justified: Results of a Real-life Monocentric Prospective Study in Chronic Migraine. Front Neurol. 2017;8:655.

78. Welch MJ, Purkiss JR, Foster KA. Sensitivity of embryonic rat dorsal root ganglia neurons to Clostridium botulinum neurotoxins. Toxicon. 2000;38(2):245-58.

79. Durham PL, Vause CV. CGRP Receptor Antagonists in the Treatment of Migraine. CNS Drugs. 2010;24(7):539-48.

80. Silberstein SD. The use of botulinum toxin in the management of headache disorders. Seminars in neurology. Thieme Medical Publishers; 2016.

81. Doods $H$, et al. CGRP antagonists: unravelling the role of CGRP in migraine. Trends Pharmacol Sci. 2007;28(11):580-7.

82. Orr SL, et al. Management of Adults With Acute Migraine in the Emergency Department: The American Headache Society Evidence Assessment of Parenteral Pharmacotherapies. Headache: The Journal of Head and Face Pain. 2016;56(6):911-40. 